\title{
Cell envelope protein profiles of Acinetobacter calcoaceticus strains isolated in hospitals
}

\author{
L. DIJKSHOORN, M. F. MICHEL and J. E. DEGENER
}

Department of Clinical Microbiology, Erasmus University Rotterdam, 40, Dr Molewaterplein, 3015 GD Rotterdam, The Netherlands

\begin{abstract}
Summary. The cell envelope protein patterns of 78 strains of Acinetobacter calcoaceticus, mainly isolated in hospitals, were analysed by sodium dodecyl sulphatepolyacrylamide gel electrophoresis (SDS-PAGE). The patterns were stable and reproducible. Comparison of the protein profiles made possible differentiation between two groups of strains. The patterns of the first group could be classified on the basis of concordance. Some profiles appeared to be associated with the epidemiological origin of the strains. The second group consisted of strains with unique patterns which could not be classified. Comparison of SDS-PAGE patterns appears to be a suitable method for the relative classification of $\boldsymbol{A}$. calcoaceticus strains of nosocomial origin.
\end{abstract}

\section{Introduction}

Despite its low virulence, Acinetobacter calcoaceticus has been described repeatedly as a cause of hospital infections (Glew et al., 1977; Ramphal and Kluge, 1979; Holton, 1982; Sherertz and Sullivan, 1985). To study the mode of transmission in hospitals, a classification system is needed by which identical strains may be recognised. Various methods of classifying $A$. calcoaceticus have been described (Marcus et al., 1969; Alexander et al., 1984; Das and Ayliffe, 1984) but none appears to be in general use. In the absence of usable classification methods, isolates of $A$. calcoaceticus are often merely divided into two groups on the basis of their saccharolytic capacity (Juni, 1984). Acid-forming strains are referred to as "var. anitratus", non-acid-forming strains as "var. lwoffi" (Rosenthal, 1978).

Protein patterns of cell membranes of gramnegative bacteria obtained by sodium dodecyl sulphate-polyacrylamide gel electrophoresis (SDSPAGE) can be used to identify strains and clones (Overbeeke and Lugtenberg, 1980; Achtman et al., 1983) and this approach has been used in epidemiological studies (Loeb and Smith, 1980; Frasch and Mocca, 1982).

The purpose of the present study was to investigate whether SDS-PAGE protein patterns could be used to classify strains of $A$. calcoaceticus. We investigated (i) whether strains of this species have

Received 27 May 1986; accepted 31 July 1986. characteristic and reproducible protein patterns when cell envelopes are subjected to SDS-PAGE, (ii) whether epidemiologically related strains have similar and unrelated strains dissimilar patterns, and (iii) whether a relationship exists between protein patterns and such easily detectable properties as acid production from glucose and haemolysis on sheep blood agar. For this purpose, 78 strains were selected from culture collections, clinical specimens, the skin of volunteers and the inanimate environment.

\section{Materials and methods}

\section{Selection and sources of strains of $A$. calcoaceticus}

The following reference strains were studied: ATCC 23055 (type strain of $A$. calcoaceticus, Beijerinck 1911), ATCC 15309 (type strain of $A$. lwoffi), ATCC 19639 (original strain Beijerinck), ATCC 13809, ATCC 9957 and NCTC 7844. Other strains included in the study were Gilardi 2890 , a strain originally obtained from B. Vogel (Basle) and four strains from the Microbiological Laboratory of Delft Technical University, designated LMD 70.9, 79.41, 81.109 and 82.54. All the other strains were isolated in the Netherlands during the period 19811985 , mainly from hospital environments. Twenty-eight strains were isolated at the University Hospital Rotterdam ( 23 from patients, 3 from healthy volunteers and 2 from the environment). The remaining 38 strains were isolated from patients in smaller hospitals in Rotterdam and Dordrecht and in the University Hospitals of Leiden, Utrecht and Nijmegen. Four strains were cultivated from soil. During the period of study there were episodes of increased isolations of $\boldsymbol{A}$. calcoaceticus in the University 
Hospitals in Rotterdam and Utrecht. The strains were kept at $-70^{\circ} \mathrm{C}$ in broth containing glycerol $10 \% \mathrm{v} / \mathrm{v}$ or in a lyophilised state.

\section{Identification of strains}

Before the isolation of cell envelopes, all the strains were identified as $A$. calcoaceticus on the basis of the following characteristics (Cowan, 1974): gram-negative coccobacilli, nonmotile (by hanging-drop method), catalase-positive, oxidase-negative (Kovács technique), nonfermenting and in general incapable of nitrate reduction. As a supplementary test the hydrolysis of Tween 80 was investigated (Sierra, 1957). All the strains gave positive results in this test, though quantitative differences were found. The strains were differentiated into saccharolytic and asaccharolytic varieties on the basis of aerobic acidification of glucose (Hugh, 1978). The capacity to produce haemolysin on Blood Agar (CM 55, Oxoid, with $5 \%$ sheep blood) was also investigated. All the media were incubated at $30^{\circ} \mathrm{C}$ except for the broth for the motility study, which was incubated at room temperature (Hugh, 1978). Motility, reaction with Gram's stain, oxidase and catalase production, and haemolysis were evaluated after $20 \mathrm{~h}$, the other tests after $48 \mathrm{~h}$.

\section{Media and growth conditions}

For the isolation of cell envelopes, stored strains were subcultured on blood agar. Various colonies of the same morphological type were inoculated into Nutrient Broth No. 2 (CM 67, Oxoid) and incubated at $30^{\circ} \mathrm{C}$ for $20 \mathrm{~h}$ with vigorous aeration.

\section{Isolation of cell-envelope fractions}

The isolation of cell-envelope fractions and the preparation of samples for electrophoresis were performed by the method described by Lugtenberg et al. (1984). Briefly, cells from 20 -h cultures were resuspended, after centrifugation, in $5 \mathrm{ml}$ of $50 \mathrm{~mm}$ Tris(hydroxymethyl)aminomethane- $\mathrm{HCl} 2 \mathrm{mM}$ ethylenediaminetetraacetic acid (EDTA), $p \mathrm{H}$ 8.5. The cells were disintegrated by ultrasonic treatments of $c .20 \mathrm{~s}$ three to six times, with cooling ( 100 watt ultrasonic disintegrator; MSE, Crawley, Sussex). The cell debris was centrifuged for $20 \mathrm{~min}$ at $900 \mathrm{~g}$. The supernate thus obtained was centrifuged for $60 \mathrm{~min}$ at $12300 \mathrm{~g}$. According to the quantity obtained, the pellet containing the cell envelopes was resuspended in $100-200 \mu$ of $2 \mathrm{mM}$ Tris- $\mathrm{HCl}, p \mathrm{H} 7 \cdot 7$.

\section{Polyacrylamide gel electrophoresis}

The proteins were separated electrophoretically and stained by the procedure of Lugtenberg et al. (1975) with the fcllowing modifications. A Protean II $16 \times 16 \mathrm{~cm}$ slab cell apparatus (Bio-Rad, Richmond, CA, USA) was used for electrophoresis. The slabs had a thickness of $1.5 \mathrm{~mm}$ and $25 \mu \mathrm{l}$ of a sample were applied per slot. Electropho- resis was performed at constant currents of $30 \mathrm{~mA}$ and $35 \mathrm{~mA}$ for the stacking and the running gel respectively. Of the three gel systems tested (A, B and C-Lugtenberg et al., 1984), system A mostly gave the best separation. This system was, therefore, used routinely. The mol. wt standards were phosphorylase B $(97400)$, bovine albumin $(66000)$, ovalbumin $(45000)$, glyceraldehyde-3-phosphate dehydrogenase subunit $(36000)$, carbonic anhydrase $(29000)$, trypsinogen $(24000)$, trypsin inhibitor (20 100) and lactalbumin (14 200) (Sigma Chemical Co., St Louis, MO, USA).

\section{Results}

\section{General characteristics and stability of cell envelope} protein patterns

The patterns of almost all the strains were characterised by one deeply stained band with an apparent mol. wt of $(39 \cdot 8-46.8) \times 10^{3}$ and various less deeply stained bands with an apparent mol. wt range of (14-97) $\times 10^{3}$.

The influence of culture conditions on the protein patterns was first studied in four strains with different protein patterns. Culture in Nutrient Broth (CM 1, Oxoid), in yeast broth (Lugtenberg et al., 1976), or on Iso-Sensitest Agar (CM 471, Oxoid) had no significant influence on the individual protein patterns. However, when the strains were cultured in an S-2 saline solution enriched with acetate $0.2 \% \mathrm{w} / \mathrm{v}$ (Monod and Wollman, 1947), all produced several extra minor protein bands with apparent mol. wts $>66 \times 10^{3}$. The influence of the growth temperature and the age of the culture was also investigated. The protein patterns of strains grown for 10 or $20 \mathrm{~h}$ at $30^{\circ} \mathrm{C}$ or $10 \mathrm{~h}$ at $37^{\circ} \mathrm{C}$ showed no qualitative differences, except for slight differences in the thickness of some minor protein bands (data not shown). In the subsequent experiments, the strains were grown in nutrient broth for $20 \mathrm{~h}$ at $30^{\circ} \mathrm{C}$. The patterns of the isolates treated in this way were stable and reproducible.

The primary criterion for distinguishing between the patterns was the position of the most deeply stained band with an apparent mol. wt in the range $(39 \cdot 8-46.8) \times 10^{3}$. However, the positions and numbers of the other protein bands were also used for discrimination. Patterns were only considered to be indistinguishable if no differences could be observed in any of the protein bands.

\section{Patterns of classifiable strains}

A great heterogeneity of patterns was found in the collection of strains studied. By application of samples of common origin in adjoining slots, several 
concordant patterns could be identified. For the purpose of this study the patterns were arbitrarily coded with capital letters. Patterns that were similar but not identical were given a capital letter, followed by a number.

A survey of strains classifiable on the basis of their protein patterns is given in table I. Prototypes of these strains are shown in fig. 1. Seventeen of the 34 clinical isolates from Rotterdam were classified as having pattern $A ; 15$ of these came from one hospital (University Hospital) and were mostly collected during a period of epidemic increase. The patterns of the six strains from Dordrecht (strains 18-23) were indistinguishable and were designated as pattern B1. Five of these strains had been isolated in a 14-month period in one hospital. Strains 24 and 25 from Utrecht and strain 26 from Nijmegen were indistinguishable. Their pattern was very similar to B1 but was designated B2 because of the presence of a more rapidly migrating protein with an apparent mol. wt of $27.5 \times 10^{3}$. The patterns of a strain from Nijmegen and a strain from Rotterdam differed from those of $\mathrm{B} 1$ and $\mathrm{B} 2$ in respect of some less deeply stained protein bands and were labelled B3 and B4 respectively. The patterns of two strains from Leiden (29 and 30) were indistinguishable from one another but differed from patterns $\mathrm{A}$ and $\mathrm{B} 1-4$ in respect of some minor proteins with mol. wt ranges of $(28 \cdot 2-29 \cdot 7) \times 10^{3}$ and $(48 \cdot 0-54.4) \times 10^{3}$. Their patterns were, therefore, classified as pattern $C$. The patterns classed as D1-3 were similar, but not identical. In these, the most deeply stained protein had an apparent mol. wt of $41.7 \times 10^{3}$, and some other characteristic proteins had apparent mol. wts of $(25 \cdot 7-26 \cdot 3) \times 10^{3}$ and $(19 \cdot 1-20 \cdot 4) \times 10^{3}$. Pattern D1 was observed in several strains from Rotterdam; two of these were isolated in one hospital. However, pattern D1 was found not only in strains from a single geographical source but also in some strains from culture collections.

The next group of patterns was found in strains

\section{Strains}
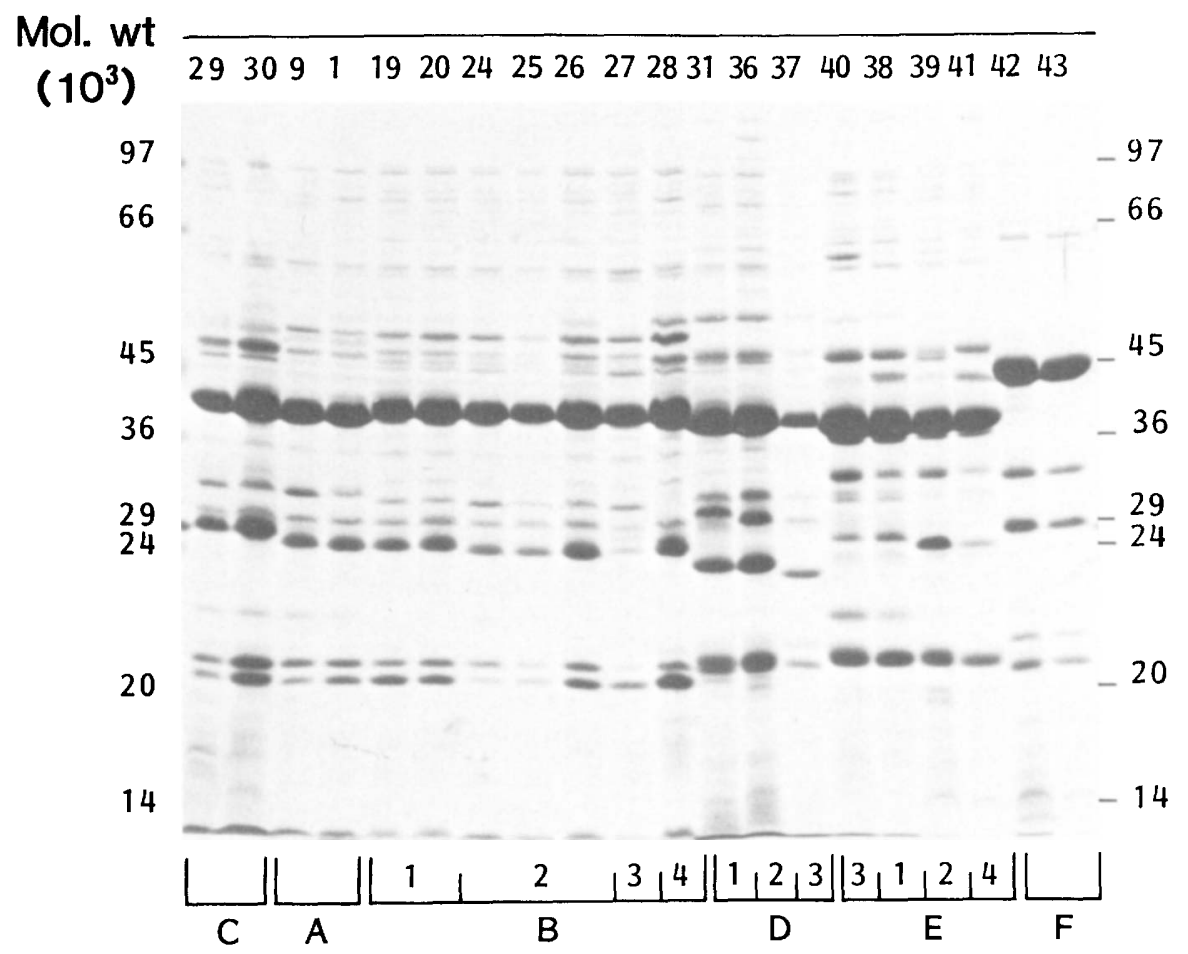

Patterns

Fig. 1. Cell envelope SDS-PAGE patterns of classified strains of $A$. calcoaceticus (table I). Classification was based on a comparison of all the protein bands. Mol. wt standards are shown on the left and right. The numbers of the strains correspond to the sequential numbers in table $I$. 
Table I. Origin and variety of strains of $A$. calcoaceticus classified on the basis of their cell envelope protein SDSPAGE pattern (Prototypes of the patterns are shown in fig. 1)

\begin{tabular}{|c|c|c|c|c|c|c|}
\hline \multirow[b]{2}{*}{$\begin{array}{l}\text { Protein } \\
\text { pattern }\end{array}$} & \multicolumn{3}{|c|}{ Source of strains* } & \multicolumn{2}{|c|}{ Varietyt } & \multirow[b]{2}{*}{$\begin{array}{c}\text { Sequential } \\
\text { no. }\end{array}$} \\
\hline & City & Hospital & $\begin{array}{l}\text { Culture } \\
\text { collection }\end{array}$ & glu & haem & \\
\hline A & $\mathbf{R}$ & $1(p)$ & & + & - & $1-12$ \\
\hline A & $\mathbf{R}$ & $1(\mathrm{p})$ & & - & - & $13-14$ \\
\hline A & $\mathbf{R}$ & $1(\mathrm{p})$ & & + & + & 15 \\
\hline A & $\mathbf{R}$ & 2 & & + & - & 16 \\
\hline A & $\mathbf{R}$ & 3 & & + & - & 17 \\
\hline $\mathrm{B} 1$ & D & $4(p)$ & & + & - & $18-22$ \\
\hline B1 & D & $5(\mathrm{p})$ & & + & - & 23 \\
\hline B2 & $\mathrm{U}$ & $1(\mathrm{p})$ & & + & - & $24-25$ \\
\hline B2 & $\mathbf{N}$ & 1 & & + & - & 26 \\
\hline B3 & $\mathbf{N}$ & 1 & & + & - & 27 \\
\hline B4 & $\mathbf{R}$ & 6 & & + & - & 28 \\
\hline $\mathrm{C}$ & $\mathrm{L}$ & 1 & & + & - & $29-30$ \\
\hline D1 & $\mathbf{R}$ & $1(\mathrm{p})$ & & + & - & $31-32$ \\
\hline D1 & $\mathbf{R}$ & 3 & & + & - & 33 \\
\hline D1 & & & LMD $79 \cdot 41$ & + & - & 34 \\
\hline D1 & & & B. Vogel & + & - & 35 \\
\hline D2 & $\mathrm{N}$ & 1 & & + & - & 36 \\
\hline D3 & $\mathbf{N}$ & 1 & & + & - & 37 \\
\hline E1 & $\mathrm{L}$ & 1 & & + & + & 38 \\
\hline E2 & $\mathbf{R}$ & $1(p)$ & & + & + & 39 \\
\hline E3 & & & $\begin{array}{l}\text { Gilardi } \\
2890\end{array}$ & + & + & 40 \\
\hline $\mathrm{E} 4$ & & & LMD 70.9 & + & + & 41 \\
\hline$F$ & $\mathbf{R}$ & 7 & & - & - & 42 \\
\hline$F$ & $\mathbf{R}$ & 6 & & - & - & 43 \\
\hline
\end{tabular}

R, Rotterdam; D, Dordrecht; U, Utrecht; N, Nijmegen; L, Leiden.

1, University Hospital; 2--5, smaller peripheral hospitals; (p) hospitals with epidemic increases of $A$. calcoaceticus.

LMD, Culture collection of Laboratory of Microbiology, Delft.

* All the strains were isolated from clinical material with the exception of strain 39 , which was cultivated from the inanimate hospital environment.

$\uparrow$ Variety based on aerobic acidification of glucose (glu) and on haemolysis (haem).

from different sources. The patterns exhibited small differences in minor proteins and were, therefore, coded as E1-4. These patterns were characterised by a major protein band (apparent mol. wt $39.8 \times$ $10^{3}$ ) that was scarcely separated from a thin band of a protein of somewhat higher mobility. Other proteins characteristic of this group had apparent mol. wts of $20.4 \times 10^{3}$ and $34.7 \times 10^{3}$.

Two isolates from Rotterdam had indistinguish- able patterns (pattern F) characterised by the low mobility of the major protein, corresponding to an apparent mol. wt of $46 \cdot 8 \times 10^{3}$.

Almost all the strains of patterns A, B1-4, C and D1-3 were saccharolytic and non-haemolytic (table I). The strains of patterns E1-4 were all saccharolytic and haemolytic. The two pattern-F strains were non-saccharolytic and non-haemolytic.

\section{Patterns of unclassifiable strains}

The patterns of 35 strains were unique and very heterogeneous. The strains in this category (table II) came not only from clinical material but also from the skin of healthy persons, from environmental specimens and from culture collections. The strains varied in saccharolytic and haemolytic properties. Several strains whose most deeply stained protein was of relatively low mobilityapparent mol. wt $(44 \cdot 8-47 \cdot 2) \times 10^{3}$-were of the asaccharolytic and non-haemolytic variety (e.g., strains 51, 44, 71 and 50; fig. 2). The mobility of the corresponding protein was greater in most of the saccharolytic, non-haemolytic strains (e.g., strains $76,68,65,78$ and 58; fig. 2). However, no clear relationship could be established between the mobility of the major protein and saccharolytic capacity.

\section{Discussion}

The membrane protein profiles of gram-negative bacteria can be influenced by culture conditions (Lugtenberg et al., 1976; Brown and Williams, 1985). In introductory experiments aimed at determining reproducibility, variation in the duration and the temperature of incubation and in the composition of some enriched media was found to have little effect. In contrast, several extra minor protein bands were observed when the cells were grown in acetate-mineral medium.

An initial survey revealed a great heterogeneity of electrophoretic patterns in the strains included in the study. When samples were classified on the basis of origin and, to a certain extent, on the basis of saccharolytic activity and haemolysis, it was possible to identify some concordant patterns. Two groups of strains could be distinguished. One group comprised strains whose patterns could be classified (table I). The other group consisted of strains with patterns that were unique and, therefore, unclassifiable (table II). Twenty-three strains in the first group were assigned to patterns A and B1. Each of these patterns appeared to be associated with a particular geographical location, because the ma- 
Table II. Origin and variety of strains with unique cell envelope protein SDS-PAGE patterns. (Several patterns are shown in fig. 2)

\begin{tabular}{|c|c|c|c|c|c|c|}
\hline \multicolumn{3}{|c|}{ Source of strains } & \multicolumn{3}{|c|}{ Variety* } & \multirow{2}{*}{$\begin{array}{c}\text { Sequential } \\
\text { no. }\end{array}$} \\
\hline City & Hospital & Sample & glu & haem & (n) & \\
\hline $\mathbf{R}$ & 1 & clin & - & - & (3) & $44,45,46$ \\
\hline $\mathbf{R}$ & 1 & volunt & - & - & (3) & $47,48,49$ \\
\hline $\mathbf{R}$ & 1 & environ & - & - & (1) & 50 \\
\hline $\mathrm{R}$ & 2 & clin & - & - & (1) & 51 \\
\hline $\mathbf{R}$ & 8 & clin & - & - & (2) & 52,53 \\
\hline $\mathrm{L}$ & 1 & clin & - & - & (1) & 54 \\
\hline$\ldots$ & $\ldots$ & environ & - & - & (1) & 55 \\
\hline $\mathbf{R}$ & 1 & clin & - & + & (1) & 56 \\
\hline $\mathrm{L}$ & 1 & clin & - & + & (1) & $57+$ \\
\hline $\mathbf{R}$ & 1 & $\operatorname{clin}$ & + & - & (1) & 58 \\
\hline $\mathrm{R}$ & 2 & clin & + & - & (1) & 59 \\
\hline $\mathrm{R}$ & 8 & clin & + & - & (1) & 60 \\
\hline $\mathrm{L}$ & 1 & clin & + & - & (2) & 61,62 \\
\hline $\mathrm{N}$ & 1 & clin & + & - & (3) & $63,64,65$ \\
\hline . & .. & environ & + & - & (3) & $66,67,68$ \\
\hline $\mathbf{R}$ & 1 & clin & + & + & (1) & 69 \\
\hline L & 1 & clin & + & + & (1) & $70 \dagger$ \\
\hline \multicolumn{7}{|c|}{ Collections } \\
\hline \multicolumn{3}{|c|}{ ATCC 15309} & - & - & & 71 \\
\hline \multicolumn{3}{|c|}{ ATCC 9957} & - & - & & 72 \\
\hline \multirow{2}{*}{\multicolumn{3}{|c|}{$\begin{array}{l}\text { LMD } 81.109 \\
\text { ATCC } 19639\end{array}$}} & - & - & & 73 \\
\hline & & & - & - & & 74 \\
\hline \multicolumn{3}{|c|}{ ATCC 23055} & $+1-\$$ & - & & 75 \\
\hline \multicolumn{3}{|c|}{ ATCC 13809} & + & - & & 76 \\
\hline \multirow{2}{*}{\multicolumn{3}{|c|}{ LMD 82.54}} & + & - & & 77 \\
\hline & & NCTC 7844 & + & - & & 78 \\
\hline
\end{tabular}

Cities and hospitals are as in table I except 8, a children's hospital.

Samples: volunt, from skin of laboratory personnel (strains 47 and 49) and hospital staff (strain 48); environ, from door (strain 50) and soil (strains 55 and 66-68); clin, from patients.

* Variety based on aerobic acidification of glucose (glu) and on haemolysis (haem); (n), number of strains investigated.

$\uparrow$ Protein patterns with two migrating major proteins close together, apparent mol. wt (41.0-42.6) $\times 10^{3}$.

$\ddagger$ The culture comprised saccharolytic and non-saccharolytic bacteria with different protein patterns.

jority of the strains with a common protein pattern had been isolated in one hospital. This pointed to an epidemiological relationship between strains of one pattern and one source. Some SDS-PAGE classification systems for gram-negatives, e.g., those for Haemophilus influenzae type b and Neisseria meningitidis, are based on differences in major proteins (Barenkamp et al., 1981; Mocca and Frasch, 1982). Because the principal protein bands of the Acinetobacter strains were not sufficiently discriminative, the entire protein profile was used for comparison. In the case of the classified strains, the differences between the patterns within a group (e.g., B1-4) and even between the patterns of groups A, Bl-4 and C (fig. 1) were small and confined to minor proteins.

The strains in this study were also differentiated on the basis of saccharolytic activity and haemolysis. The taxonomic significance, however, of the capacity to acidify sugar has been questioned (Henriksen, 1973). Saccharolytic and asaccharolytic strains are assumed not to differ in pathogenicity (Rosenthal, 1978). Nonetheless, nosocomial infections appear to be frequently associated with acinetobacters of the saccharolytic variety (Glew $e t$ al., 1977; Ramphal and Kluge, 1979; Holton, 1982). With few exceptions, the classified strains which were assigned to patterns A, B1-4, C and D1-3 were of the saccharolytic variety. On the basis of an extensive study of strains of Escherichia coli, Achtman et al. (1983) asserted that membrane protein patterns and other parameters such as biotype are not causally related. In their view, protein patterns are more suitable for identifying clonal relationship.

Thirty-five of the 78 strains had unique protein patterns which could not be classified. These strains were of varied geographical and ecological origin and also differed in their saccharolytic and haemolytic properties. The heterogeneity of protein patterns observed suggests that there are many different Acinetobacter strains. Other studies have led to the conclusion that Acinetobacter is a heterogeneous genus. This followed from the observation that the $\mathrm{mol} \% \mathrm{G}+\mathrm{C}$ of the bacterial DNA of Acinetobacter strains can vary over a range of 38-47 (Henriksen, 1976). Moreover, it has been found that strains can differ considerably in nutritional properties (Baumann et al., 1968). Recently 12 DNA hybridisation groups (genospecies) have been found among a collection of 85 Acinetobacter strains; 28 phenotypic characteristics were found useful for the differentiation of these genospecies (Bouvet and Grimont, 1986).

The purpose of this study was to investigate whether SDS-PAGE protein patterns can be used to classify acinetobacters. In view of the heterogeneity of the patterns that were observed, development of an absolute classification method is not possible at present. Because the patterns were stable and a relationship with particular geographical sources was found for some patterns, it would, 


\section{Strains}

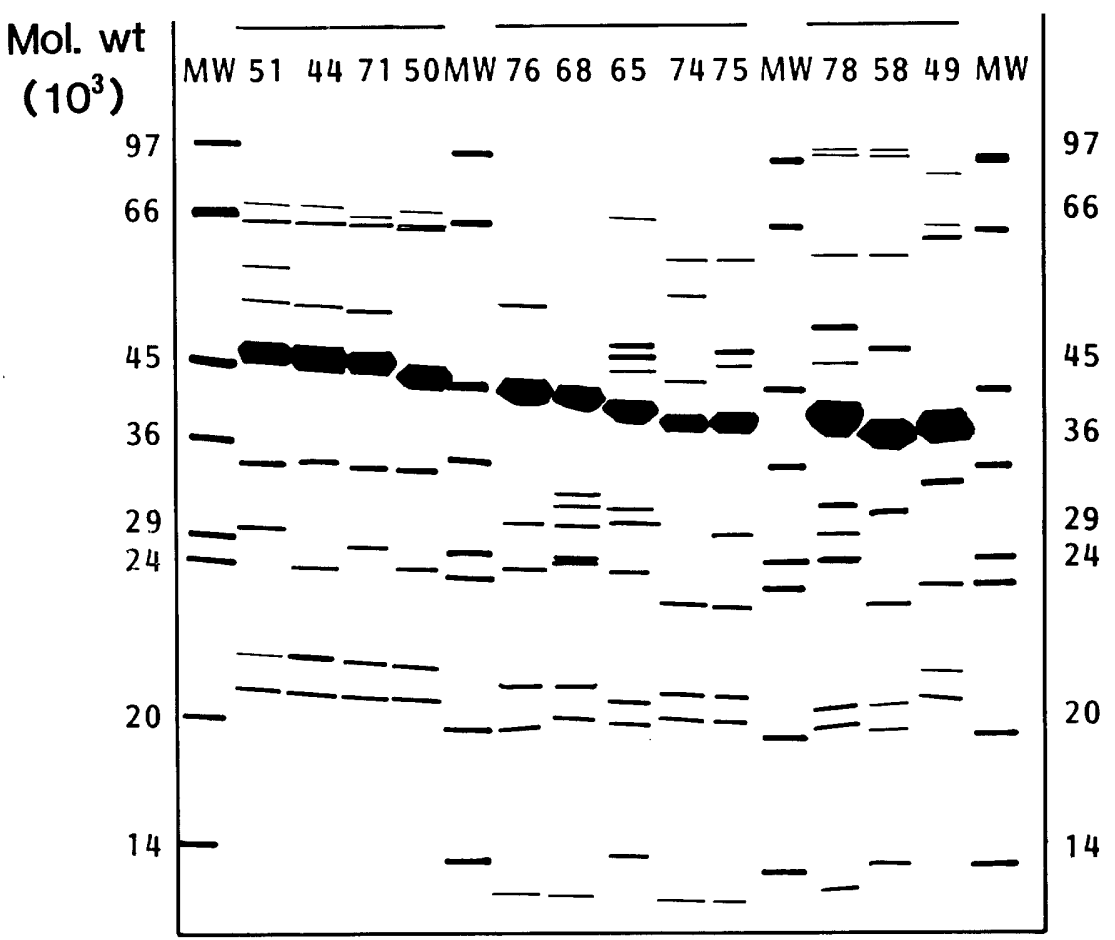

Fig. 2. Cell envelope protein SDS-PAGE patterns of $12 \mathrm{~A}$. calcoaceticus strains which could not be classified. Details of the strains are given in table II. Mol. wt standards are shown on the left and right and between sets of strains (MW).

however, appear that the method can be used for the relative classification of strains in well-defined clinical situations.

Though a relative classification of this kind can be useful for nosocomial epidemiology, it remains desirable that a general classification method should be developed. The combined use of different methods, such as DNA hybridisation, SDS-PAGE typing, immunoblotting, serotyping and biotyping,

\section{REFERENCES}

Achtman M, Mercer A, Kusecek B, Pohl A, Heuzenroeder M, Aaronson W, Sutton A, Silver R P 1983 Six widespread bacterial clones among Escherichia coli $\mathrm{K} 1$ isolates. Infection and Immunity 39:315-335.

Alexander M, Ismail F, Jackman P J H, Noble W C 1984 Fingerprinting Acinetobacter strains from clinical sources by numerical analysis of electrophoretic protein patterns. Journal of Medical Microbiology 18:55-64.

Barenkamp S J, Munson R S, Granoff D M 1981 Subtyping isolates of Haemophilus influenzae type b by outer-membrane protein profiles. Journal of Infectious Diseases 143: 668-676. could contribute to the identification of strains of epidemiological or clinical importance.

This study was financed by the "Praeventiefonds" of The Netherlands, grant no. 28-1070. We thank Dr A. S. Lampe, Dr B. T. Lim, Professor G. C. J. van der Ploeg, Ir J. van der Toorn, Dr J. K. Schönfeld and Dr C. M. J. E. Vandenbroucke for providing the strains and Mrs P. Jansen for secretarial help. We are very grateful to Professor B. Lugtenberg for technical advice and helpful discussions.

Baumann P, Doudoroff M, Stanier R Y 1968 A study of the Moraxella group. II. Oxidative-negative species (genus Acinetobacter). Journal of Bacteriology 95:1520-1541.

Bouvet P J M, Grimont P A D 1986 Taxonomy of the genus Acinetobacter with the recognition of Acinetobacter baumannii sp. nov., Acinetobacter haemolyticus sp. nov., Acinetobacter johnsonii sp. nov. and Acinetobacter junii sp. nov. and emended descriptions of Acinetobacter calcoaceticus and Acinetobacter lwoffi. International Journal of Systematic Bacteriology 36:228-240.

Brown M R W, Williams P 1985 The influence of environment on envelope properties affecting survival of bacteria in infections. Annual Review of Microbiology 39:527-556. 
Cowan S T 1974 Cowan and Steel's Manual for the identification of medical bacteria, 2nd edn. Cambridge University Press, Cambridge.

Das B C, Ayliffe G A J 1984 Serotyping of Acinetobacter calcoaceticus. Journal of Clinical Pathology 37: 1388-1391.

Frasch C E, Mocca L F 1982 Strains of Neisseria meningitidis isolated from patients and their close contacts. Infection and Immunity 37: 155-159.

Glew R H, Moellering R C, Kunz L J 1977 Infections with Acinetobacter calcoaceticus (Herellea vaginicola): clinical and laboratory studies. Medicine (Baltimore) 56:79-97.

Henriksen S D 1973 Moraxella, Acinetobacter, and the Mimeae. Bacteriological Reviews 37:522-561.

Henriksen S D 1976 Moraxella, Neisseria, Branhamella, and Acinetobacter. Annual Review of Microbiology 30:63-83.

Holton J 1982 A report of a further hospital outbreak caused by a multi-resistant Acinetobacter anitratus. Journal of Hospital Infection 3: 305-909.

Hugh R 1978 Classical methods for isolation and identification of glucose nonfermenting Gram-negative rods. In: Gilardi G L (ed) Glucose nonfermenting Gram-negative bacteria in clinical microbiology. CRC Press, West Palm Beach, FL, pp 3 and 6.

Juni E 1984 Acinetobacter Brisou and Prévot 1954, 727. In: Krieg N R (ed) Bergey's Manual of systematic bacteriology vol. 1. Williams and Wilkins, Baltimore, pp 303-307.

Loeb M R, Smith D H 1980 Outer membrane protein composition in disease isolates of Haemophilus influenzae: pathogenic and epidemiological implications. Infection and Immunity 30: 709-717.

Lugtenberg B, Meijers J, Peters R, van der Hoek P, van Alphen L 1975 Electrophoretic resolution of the "major outer membrane protein" of Escherichia coli K12 into four bands. FEBS Letters 58:254-258.

Lugtenberg B, Peters R, Bernheimer H, Berendsen W 1976 Influence of cultural conditions and mutations on the composition of the outer membrane proteins of Escherichia coli. Molecular and General Genetics 147:251-262.

Lugtenberg B, van Boxtel R, de Jong M 1984 Atrophic rhinitis in swine: correlation of Pasteurella multocida pathogenicity with membrane protein and lipopolysaccharide patterns. Infection and Immunity 46:48-54.

Marcus B B, Samuels S B, Pittman B, Cherry W B 1969 A serologic study of Herellea vaginicola and its identification by immunofluorescent staining. American Journal of Clinical Pathology 52:309-319.

Mocca L F, Frasch C E 1982 Sodium dodecyl sulfatepolyacrylamide gel typing system for characterization of Neisseria meningitidis isolates. Journal of Clinical Microbiology 16:240-244.

Monod J, Wollman E 1947 l'Inhibition de la croissance et de l'adaptation enzymatique chez les bactéries infectées par le bactériophage. Annales de l'Institut Pasteur 73:937-956.

Overbeeke N, Lugtenberg B 1980 Major outer membrane proteins of Escherichia coli strains of human origin. Journal of General Microbiology 121 : 373-380.

Ramphal R, Kluge R M 1979 Acinetobacter calcoaceticus variety anitratus: an increasing nosocomial problem. American Journal of the Medical Sciences 277:57-66.

Rosenthal S L 1978 Clinical role of Acinetobacter and Moraxella. In: Gilardi G L (ed) Glucose nonfermenting Gram-negative bacteria in clinical microbiology. CRC Press, West Palm Beach, FL, pp 109 and 110.

Sherertz R J, Sullivan M L 1985 An outbreak of infections with Acinetobacter calcoaceticus in burn patients: contamination of patients' mattresses. Journal of Infectious Diseases $151: 252-258$.

Sierra G 1957 A simple method for the detection of lipolytic activity of micro-organisms and some observations on the influence of the contact between cells and fatty substrates. Antonie van Leeuwenhoek 23: 15-22. 